\title{
FAUNA EKINODERMATA DI PERAIRAN PULAU KEFFING, SERAM BAGIAN TIMUR, MALUKU
}

\section{ECHINODERMS FAUNA AT KEFFING ISLAND WATERS, EAST SERAM, MALUKU}

\author{
Abdul Wahab Radjab\#, Dominggus Polnaya, Wempi Barends, dan Ahmad Ainarwowan \\ Pusat Penelitian Laut Dalam-LIPI \\ Jl. Y. Syaranamual, Guru-Guru Poka. Ambon 97233 \\ Email: radjab002@gmail.com
}

(Diterima: 26 Februari 2021; Diterima setelah perbaikan: 18 Oktober 2021; Disetujui: 21 Oktober 2021)

\begin{abstract}
ABSTRAK
Perairan pulau Keffing memiliki ekosistem mangrove, ekosistem lamun, maupun ekosistem karang yang masih relatif baik, perairan pantai pulau Keffing didominasi oleh habitat pasir, pasir kasar dan lumpur yang sangat menunjang kehidupan fauna ekinodermata. Penelitian tentang ekinodermata di perairan pulau Keffing perlu dilakukan mengingat akhir-akhir ini kurangnya data dan informasi tentang biota tersebut. Tujuan dari penelitian ini adalah untuk mengetahui keberadaan, dominasi dan kepadatan ekinodermata di perairan pulau Keffing. Penelitian ini dilakukan pada bulan Nopember-Desember 2018, pengambilan sampel dilakukan dengan metoda transek kuadrat dan koleksi bebas pada 3 lokasi di perairan pulau Keffing. Hasil penelitian menunjukan bahwa ekinodermata yang dijumpai berjumlah 7 jenis, 7 famili, dan 4 kelas. Nilai dominasi tertinggi sebesar 0,003 yang menunjukan bahwa terdapat dominasi spesies tertentu yaitu Holothuroidea. Sedangkan kepadatan ekinodermata berdasarkan kelompok kelas pada perairan pulau Keffing tertinggi pada kelas Holothuroidea, famili Stichopodidae dari jenis Stichopus variegatus sebesar $0,705 \mathrm{ind} / \mathrm{m}^{2}$ yang didominasi oleh habitat pasir yang ditumbuhi lamun.
\end{abstract}

KATA KUNCI: Fauna; ekinodermata; perairan pulau Keffing; Seram Bagian Timur; Maluku

\begin{abstract}
The waters of Keffing Island have mangrove ecosystems, seagrass ecosystems, and coral ecosystems that are still relatively good, the coastal waters of Keffing Island are dominated by habitats of sand, coarse sand and mud which are very supportive of the life of ecinoderm fauna. Research on echinoderms in the waters of Keffing Island needs to be carried out considering the recent lack of data and information on these biota. The purpose of this study was to determine the presence, dominance and density of echinoderms in the waters of Keffing Island. This research was conducted in November-December 2018, sampling was carried out by the quadratic transect method and free collection at 3 locations in the waters of Keffing Island. The results showed that the echinoderms were 7 species, 7 families, and 4 classes. The highest dominance value is 0.003 which indicates that there is dominance of a particular species, namely Holothuroidea. While the density of echinoderms based on class groups in the waters of Keffing Island was the highest in the Holothuroidea class, the Stichopodidae family of the Stichopus variegatus type of $0.705 \mathrm{ind} / \mathrm{m}^{2}$ which was dominated by sand habitat overgrown with seagrass.
\end{abstract}

KEYWORDS: Fauna; echinoderm; Keffing Island waters; Eastern Seram; Maluku

\section{PENDAHULUAN}

Fauna ekinodermata dapat dijumpai hampir di seluruh perairan pantai, mulai dari daerah pasang surut

\footnotetext{
\# Korespondensi: Pusat Penelitian Laut Dalam- LIPI
}

E-mail: radjab002@gmail.com sampai perairan dalam dengan kedalaman antara 0,5 sampai 40 meter. Fauna ekinodermata berperan sebagai hewan penting dalam ekosistem laut dan merupakan bagian dari komponen dalam rantai makanan, sebagai pemakan detritus dan hewan kecil 
lainnya (Jailani et al., 2020). Echinodermata secara ekologi disebut sebagai organisme yang berperan dalam menjaga keseimbangan ekosistem laut, dimana Holothuroidea dan Echinoidea memiliki peranan sebagai pendaur ulang nutrien (Triana et al., 2015 dalam Sese et al., 2018).

Anggota filum ini termasuk Holothuroidea (teripang), Echinoidea (bulu babi), Asteroidea (bintang laut), Ophiuroidea (bintang rapuh), dan Crinoidea (bunga lili laut). Setiap kelas Echinodermata memiliki ciri khas dan habitat yang berbeda. Asteroidea dan Echinoidea biasanya ditemukan di daerah intertidal dengan substrat berbatu (Andilala et al., 2020). Pada umumnya setiap jenis memiliki habitat yang spesifik, seperti misalnya Stichopus variegathus yang sering dijumpai di daerah berpasir atau pasir berlumpur yang banyak ditumbuhi lamun. Ekosistem lamun, ekosistem pasir dan ekosistem terumbu karang merupakan habitat tempat hidup berbagai jenis biota laut. Ekinodermata menempati berbagai zona di ekosistem lamun, zona pertumbuhan alge, zona tubir dan lereng terumbu karang. Habitat echinodermata dapat ditemukan hampir pada semua ekosistem laut, namun paling banyak ditemukan pada zona pantai intertidal yang ditumbuhi oleh padang lamun (Syamsul et al., 2021).

Keanekaragaman hayati ekosistem laut sangat berguna untuk memahami pola ekologi, fungsi ekosistem dan manajemen konservasi (Setyastuti et al., 2018 dalam Muzaki et al., 2019). Kehadiran dan peranan ekinodermata pada ekosistem pasir, ekosistem lamun dan ekosistem terumbu karang telah dilaporkan oleh Clark \& Rowe (1971). Faktor fisikkimia laut meliputi salinitas, $\mathrm{pH}$, arus, suhu, dan kecerahan yang selalu berubah-ubah sangat berpengaruh terhadap kehidupan organisme di daerah pasang surut. Faktor penting lain yang mempengaruhi sebaran ekinodermata adalah topografi rataan suatu pulau di samping pakan dan cara makan (Rowe \& Doty, 1977). Selanjutnya dikatakan bahwa densitas hewan laut bergantung pada temperatur, salinitas, arus, kondisi substrat dan habitat sangat menentukan keberadaan fauna ekinodermata.

Perairan Pulau Keffing memiliki ekosistem lamun dan alge, ekosistem mangrove dan ekosistem karang. Perairan pantai Pulau Keffing didominasi oleh pasir halus dan lumpur kasar dan pasir halus yang ditumbuhi lamun dan sangat menunjang kehidupan fauna ekinodermata. Informasi mengenai keberadaan ekinodermata perlu diketahui karena tidak sedikit jumlah jenis biota yang termasuk dalam kelompok ini mempunyai nilai ekonomi yang cukup tinggi di pasaran nasional maupun internasional. Untuk itu kegiatan seperti mengetahui keberadaan dan monitoring sumberdaya ekinodermata yang ada pada suatu perairan merupakan kegiatan yang perlu dilakukan. Distribusi lokal dan perkembangan biota ekinodermata sangat tergantung pada faktor substrat, jumlah dan jenis makanan yang tersedia di daerah perairan dimana biota tersebut berada (de Beer, 1990).

Mengingat untuk mengetahui dan monitoring fauna ekinodermata jarang dan relatif sedikit yang dilakukan, maka penelitian ini dilakukan untuk mengetahui keberadaan, potensi untuk mendata fauna ekinodermata tersebut. Tujuan dari penelitian ini adalah untuk mengetahui keberadaan ekinodermata di perairan Pulau Keffing.

\section{BAHAN DAN METODE}

\section{Waktu dan lokasi}

Penelitian ini dilaksanakan pada bulan Nopember Desember 2018 di perairan Pulau Keffing pada daerah berpasir, lamun, daerah yang ditumbuhi makroalge pada 3 lokasi pengamatan yang dapat dilihat pada Gambar 1 dan Tabel 1.

\section{Alat dan Bahan}

Pada kegiatan penelitian ini digunakan peralatan untuk keperluan penelitian di lapangan dan laboratorium antara lain meteran rol, frame (kuadrat), masker-snorkel, fin, kamera bawah air, papan pencatat bawah air, kantong plastik, karet gelang, spidol permanen, pensil, buku data dan alkohol $70 \%$ (Tabel 2).

\section{Metode Pengambilan Sampel dan Analisis Data}

Penelitian ini menggunakan metoda transek dan koleksi bebas, untuk lokasi-lokasi yang biotanya sangat jarang, maka dilakukan koleksi bebas dengan cara berenang "snorkeling" menyusuri perairan pantai. Ekinodermata yang dijumpai saat koleksi bebas diamati secara visual komposisi jenis dan dihitung jumlah individu dari masing-masing jenis dan diamati tipe substratnya. Sampel yang diperoleh langsung diidentifikasi di lapangan, sedangkan sampel yang belum teridentifikasi dimasukan ke dalam kantong plastik dan diawetkan dengan alkohol untuk dilakukan identifikasi di laboratorium. Identifikasi dilakukan menurut literatur yang ditulis oleh Clark \& Rowe (1971). Analisis data dilakukan dengan cara mangambil rata-rata untuk menghitung beberapa indeks yaitu Frekuensi Kehadiran $\left(\mathrm{F}_{i}\right)$, Kepadatan $\left(\mathrm{D}_{j}\right)$ dan Dominasi (D) dengan perhitungan menurut literatur yang dikembangkan oleh Saito et al. (1977) dalam Rahayu (1984), Indeks keanekaragaman jenis (H) (Shannon, 1948), Indeks kemerataan (F) (Margalf, 1957). 


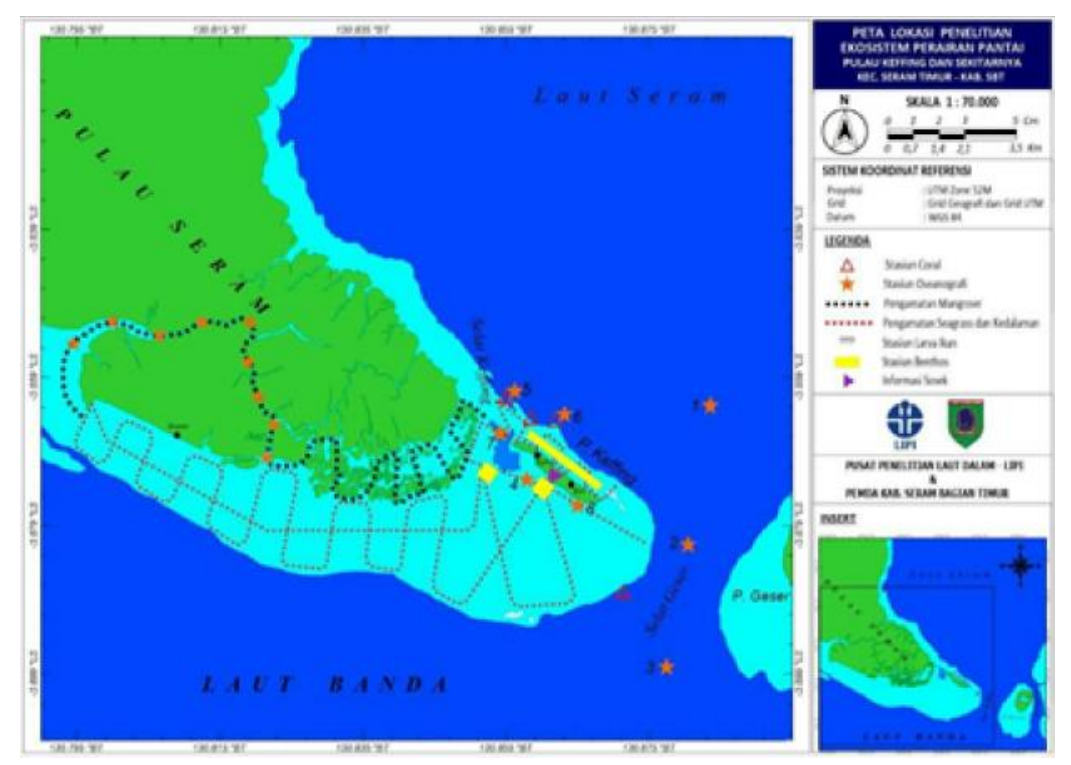

Gambar 1. Peta lokasi penelitian.

Figure 1. Map of the research location.

Tabel 1. Rincian kegiatan penelitian

Table 1. Details of research activities

\begin{tabular}{clll}
\hline No. & Stasiun Penelitian & Aktifitas & Habitat \\
\hline 1. & Bagian Selatan P. Keffing & Koleksi bebas & Pasir kasar, lamun, makroalge \\
2. & Bagian Utara P. Keffing & Koleksi bebas & Pasir kasar, lamun, makroalge \\
3. & Bagian Barat P. Keffing & Koleksi bebas & Pasir kasar, lamun, makroalge \\
\hline
\end{tabular}

Tabel 2. Alat dan bahan yang digunakan selama pengambilan dan analisis

Table 2. Tools and materials used during sample collection and analysis

\begin{tabular}{cll}
\hline No. & \multicolumn{1}{c}{ Alat/bahan } & \multicolumn{1}{c}{ Fungsi } \\
\hline 1 & Meteran rol & Alat bantu ukur panjang transek \\
2 & Frame (kuadrat) & Alat bantu pengukur luasan sampling \\
3 & Masker & Alat bantu melihat sample dalam air \\
4 & Snorkel & Alat bantu pernapasan dalam air \\
5 & Fin & Alat bantu berenang \\
6 & Kamera & Alat untuk dokumentasi \\
7 & Papan pencatat & Alat untu mencatat \\
8 & Kantong plastik & Bahan mengisi sampel \\
9 & Karet gelang & Bahan pengikat kantong plastik \\
10 & Spidol permanen & Bahan memberi kode sampel \\
11 & Pensil & Bahan mencatat data \\
12 & Buku data & Bahan mencatat data \\
13 & Alkohol 70 $\%$ & Bahan mengawetkan sampel \\
\end{tabular}

\section{HASIL DAN BAHASAN}

Hasil penelitian yang telah dilakukan di perairan Pulau Keffing secara keseluruhan diperoleh 352 individu yang terdiri dari 7 jenis, 7 famili, 4 kelas yang tergolong filum ekinodermata, sebagaimana dapat dilihat pada Tabel 3. 
Tabel 3. Total individu ekinodermata hasil koleksi bebas di perairan Pulau Keffing Table 3. Total individual echinoderms from free collection in Keffing Island waters

\begin{tabular}{|c|c|c|c|c|}
\hline No & $\begin{array}{c}\text { Lokasi } \\
\text { Penelitian }\end{array}$ & Kelas & Famili & Spesies \\
\hline \multirow{7}{*}{1} & \multirow{7}{*}{ Bagian Selatan } & Holothurioidea & Holothuriidae & Holothuria edulis \\
\hline & & (Teripang) & Stichopodidae & Stichopus variegatus \\
\hline & & Echinoidea & Diadematidae & Diadema setosum \\
\hline & & (Bulu babi) & Toxopneustidae & Tripneustes gratilla \\
\hline & & Asteroidea & Oriasteridae & Protoreaster nodosus \\
\hline & & (Bintang laut) & Ophidiasteridae & Lynckia laevigata \\
\hline & & $\begin{array}{l}\text { Ophiuroidea } \\
\text { (Bintang mengular) }\end{array}$ & Ophiocomidae & Ophiocoma erinaceus \\
\hline \multirow{5}{*}{2} & \multirow{5}{*}{ Bagian Utara } & Holothuroidea & Holothuriidae & Holothuria edulis \\
\hline & & (Teripang) & Stichopodidae & Stichopus variegatus \\
\hline & & Echinoidea & Echinodidae & Diadema setosum \\
\hline & & (Bulu babi) & Toxopneustidae & Tripneustes gratilla \\
\hline & & $\begin{array}{l}\text { Asteroidea } \\
\text { (Bintang laut) }\end{array}$ & Oriasteridae & Protoreaster nodosus \\
\hline \multirow{3}{*}{3} & \multirow{3}{*}{ Bagian Barat } & $\begin{array}{l}\text { Holothuroidea } \\
\text { (Teripang) }\end{array}$ & Stichopodidae & Stichopus variegatus \\
\hline & & $\begin{array}{l}\text { Echinoidea } \\
\text { (Bulu babi) }\end{array}$ & Echinodidae & Diadema setosum \\
\hline & & $\begin{array}{l}\text { Asteroidea } \\
\text { (Bintang laut) }\end{array}$ & Oriasteridae & Protoreaster nodosus \\
\hline
\end{tabular}

\section{Frekuensi Kehadiran}

Hasil penelitian yang diperoleh pada setiap lokasi penelitian menunjukan bahwa, dari 4 kelas yang tergolong dalam ekinodermata adalah pada Bagian Selatan yang banyak ditumbuhi mangrove mempunyai frekuensi kehadiran tertinggi pada kelas Holothuroidea (Gambar 2).

Pada perairan Pulau Keffing diperoleh frekuensi kehadiran tertinggi pada kelasHolothuroideadan diikuti pada tiga kelas lainnya yaitu Echinoidea, Asteroidea dan Ophiuroidea. Frekuensi kehadiran berperan penting dalam mengetahui tingkat kehadiran setiap jenis pada tiap lokasi pengamatan. Melihat nilainilai tersebut di atas terlihat bahwa frekwensi kehadiran rata-rata dari kelas Holothuroideadi perairan Pulau Keffing relatif mempunyai nilai yang sangat tinggi yaitu sebesar $50 \%$. Hal ini mengindikasikan bahwa sumberdaya ekinodermata khusunya kelas Holothuroidea masih sangat gampang dijumpai jika dibandingkan dengan daerah yang pernah diamati di perairan Jikumerasa, Kabupaten Buru, dimana diperoleh nilai frekuensi kehadiran tertinggi yaitu dari kelas Holothuroidea sebesar 2,86 \% (Radjab \& Rumahenga, 2012).

\section{Kepadatan Populasi (ind $/ \mathrm{m}^{2}$ )}

Kepadatan ekinodermata (ind $/ \mathrm{m}^{2}$ ) berdasarkan kelompok kelas pada perairan Pulau Keffing, kepadatan tertinggi dijumpai di perairan Bagian Selatan pada kelas Holothuroidea (teripang) sebesar 0,705 ind $/ \mathrm{m}^{2}$, sedangkan di perairan bagian Barat dan Utara mempunyai nilai kepadatan yang lebih rendah. Nilai kepadatan yang diperoleh di perairan ini relatif cukup tinggi dibandingkan dengan daerah Jikumerasa, Kabupaten Buru. Kepadatan populasi teripang didominasi oleh jenis Sichopus variegatus. Kepadatan yang didominasi oleh satu jenis kemungkinan disebabkan oleh faktor kimiawi perairan yang mendukung untuk pertumbuhan jenis teripang tersebut untuk bereproduksi.

Setiap jenis teripang di Indonesia memiliki kebiasaan waktu memijah yang berbeda-beda. Teripang jenis Holothuria scabra misalnya biasa memijah pada bulan April sampai Juni. Sedangkan teripang jenis Holothuria tubulosa biasa memijah pada bulan Agustus sampai September dan teripang jenis Stichopus japonecus biasanya antara bulan Mei sampai Juni. Temperatur dan salinitas merupakan 2 faktor yang sangat berpangaruh pada reproduksi teripang. Pada reproduksi seksual, temperatur mempunyai 2 peranan, yaitu mengontrol kematangan gonad dan waktu 
pemijahan. Temperature air laut di atas $21^{\circ} \mathrm{C}$ memungkinkan terjadinya pematangan gonad dan pemijahan sepanjang tahun (Mustofa, 2014).

Reproduksi secara aseksual pada teripang dilakukan dengan pemotongan / pembelahan tubuh (fission), tidak ada hubungannya antara perkembangan gonad dengan peristiwa fission. Fission terjadi karena kondisi alam tanpa pengaruh dari reproduksi secara seksual (Bakus, 1973). Menurut Doty (1977) dalam Mustofa (2014), faktor yang menyebabkan pembelahan belum banyak diketahui namun pembelahan umumnya terjadi pada daerah pasang surut. Daerah ini dipengaruhi arus dan temperatur yang bervariasi. Peningkatan temperature yang terjadi terutama pada saat surut di daerah tropis menyebabkan terjadinya pembelahan.

Secara keseluruhan kepadatan rata-rata (ind $/ \mathrm{m}^{2}$ ) berdasarkan kelompok kelas pada setiap lokasi penelitian perairan Pulau Keffingdapat dilihat pada Gambar 3.
Dari hasil analisis data diiperoleh kepadatan ekinodermata (ind $/ \mathrm{m}^{2}$ ) pada semualokasi penelitian menunjukan bahwa kepadatan tertinggi pada bagian Selatan yang lebih banyak ditumbuhi lamun dan mangrove adalah kelas Holthuroideasebesar 0,705 ind/ $\mathrm{m}^{2}$ dan di bagian barat dan Utaradijumpai nilainya lebih rendah. Secara keseluruhan kepadatan (ind $/ \mathrm{m}^{2}$ ) berdasarkan kelompok kelas pada semua lokasi penelitian dan rata-rata kepadatan (\%) di perairan Pulau Keffing adalah $0,027 \mathrm{ind} / \mathrm{m}^{2}$. Kepadatan ekinodermata berbeda-beda menurut kelas dan kebiasaan hidupnya, ada yang berkelompok dan ada yang soliter. Kepadatan menurut kelas tersebut dapat disebabkan oleh kemampuan masing-masing jenis menempati habitat yang dalam hal ini berhubungan dengan perkembang biakan. Kecil atau rendahnya nilai kepadatan Echinoidea, Asteroidea dan Ophiuroidea mungkin disebabkan oleh kurangnya kemampuan bersaing dalam menempati habitat. Sedangkan adanya nilai kepadatan Echinoidea kemungkinan disebabkan oleh sifat adaptasi dan kemampuan yang besar untuk menempati habitat.

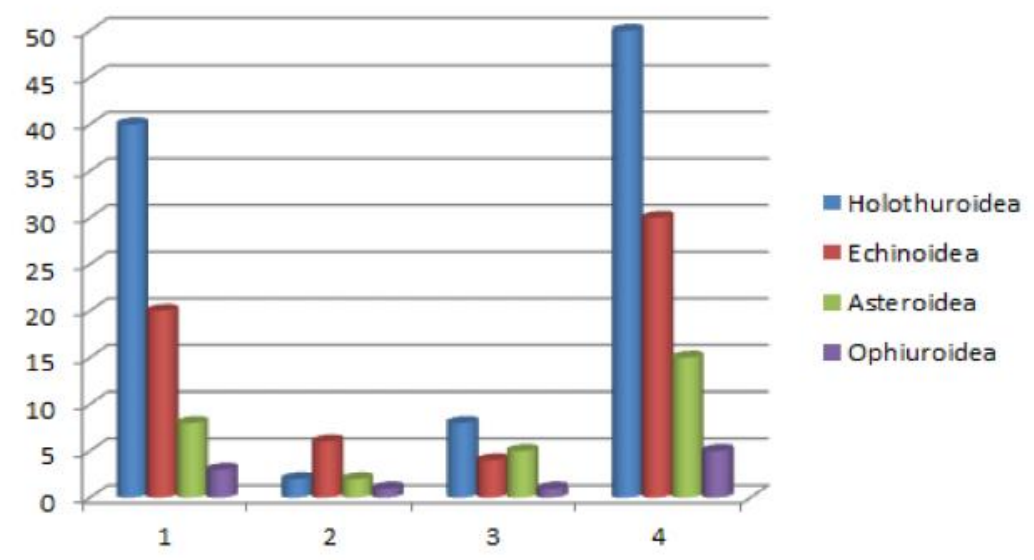

Gambar 2. Frekwensi kehadiran ekinodermata di perairan pulau Keffing.

Figure 2. Frequency of presence of echinoderms in Keffing Island waters.

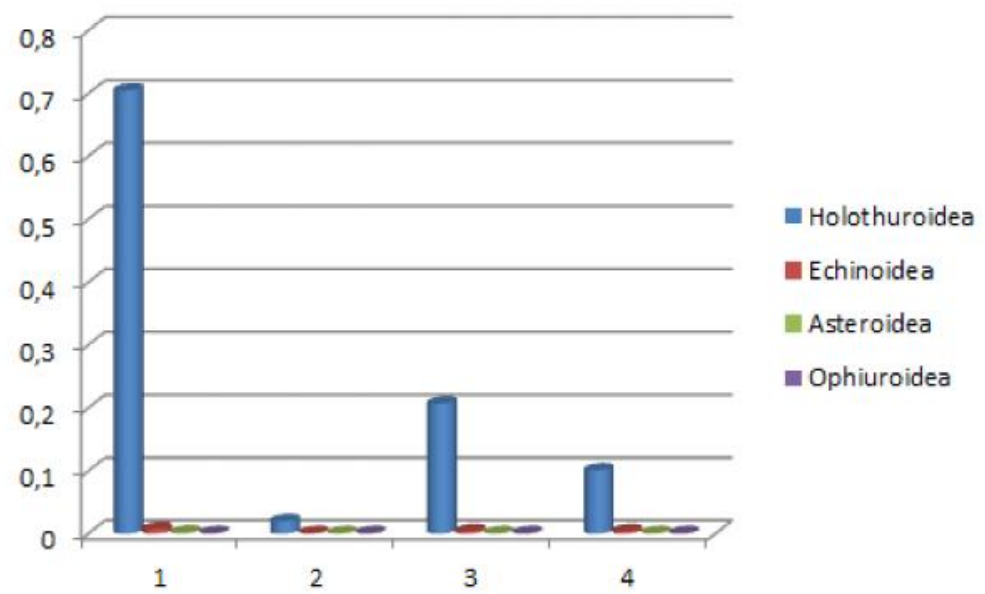

Gambar 3. Kepadatan populası ekınodermata dı pulau Kettıng.

Figure 3. Population density of echinoderms on Keffing Island. 


\section{Keanekaragaman, Dominansi, Kemerataan, dan Pola Sebaran Jenis}

Hasil analisis beberapa indeks ekologi ekinodermata di perairan Pulau Keffing. Nilai indeks keanekaragaman, dominansi, kemerataan dan sebaran ekinodermata di perairan Pulau Keffing dapat dilihat pada Gambar 4.

\section{a. Keanekaragaman}

Indeks keanekaragaman jenis ekinodermata pada daerah pasang surut di perairan Pulau Keffing secara umumsebesar 0,001 dengan demikian menunjukan bahwa keanekaragaman tiap lokasi penelitian adalah sangat rendah. Indeks dominansi ekinodermata pada daerah pasang surut secara keseluruhan sebesar 0,002 dengan demikian menunjukan bahwa lokasi penelitian terdapat dominansi spesiesdi bagian Selatan. Indeks kemerataan ekinodermata pada daerah pasang surut secara keseluruhan sebesar 0,001 dengan demikian menunjukan bahwa, kemerataan spesies pada setiap lokasi penelitian tidak menyebar secara merata. Indeks pola sebaran jenis ekinodermata pada daerah pasang surut secara keseluruhan sebesar 0,001 dengan demikian menunjukan bahwa, pola sebaran jenis tiap lokasi penelitian adalah tidak beragam.

Secara umum nilai indeks keanekaragaman 0,001 sebagaimana dapat dilihat pada tabel 3, dengan demikian dapat dikatakan bahwa tingkat keragaman ekinodermata pada setiap lokasipenelitian dapat dikatagorikan keanekaragaman rendah. Suatu komunitas memiliki tingkat keragaman yang tinggi apabila nilai indeks Shannon 4,00, sedangkan tingkat keragaman sedang indeks Shannon adalah antara 1,003,00 dan tingkat keragaman rendah jika indeks Shannon adalah 0,00 (Odum, 1971). Selanjutnya dikatakan bahwa apabila nilai indeks keragaman mendekati nilai 4 maka dikatakan beragam (Odum, 1971). Nilai keanekaragaman rendah yang dijumpai pada lokasi penelitian berkaitan erat dengan keadaan lokasi di dalam teluk, yang mana sebagian besar arealnya didominasi oleh substrat hasil sedimentasi dari daratan. Dengan demikian biota yang ada pada lokasi tersebut tidak dapat mengambil makanan dan oksigen dengan baik dan mendapat tekanan fisik berupa perubahan sedimen atau habitat. Chelazzi \&Vannini (1980) mempelajari zonasi biota di perairan pantai selatan Somalia mendapatkan bahwa kekayaan jenis meningkat di daerah rataan terumbu yang selalu terendam air dan mempunyai dasar yang kompleks. Selanjutnya dikatakan bahwa kekayaan jenis di rataan terumbu pada umumnya tinggi disebabkan oleh kecepatan pertukaran massa air, oksigen yang tinggi dan tekanan panas matahari yang rendah (Taylor, 1971).

Apabila indeks keanekaragaman Shannon suatu komunitas kurang dari 3,00 berarti komunitas tersebut kurang beragam. Hal ini dijelaskan juga bahwa tinggi rendahnya keanekaragaman dipengaruhi oleh banyak faktor, diantaranya adalah jumlah dan jenis kualitas lingkungan. Semakin banyak jumlah spesies dengan proporsi yang seimbang menunjukkan keanekaragaman semakin tinggi (Leksono, 2007). Indeks keanekaragaman ekinodermata pada setiap stasiun penelitian dikatagorikan keanekaragaman rendah, hal ini diakibatkan oleh: 1) jumlah jenis dan kualitas perairan, serta 2) penangkapan ekinodermata yang dilakukan secara terus menerus untuk kepentingan komersial, tanpa memperhatikan ukuran jenis spesies dan aspek sirkulasi reproduksi.

\section{b. Dominasi}

Secara umum nilai indeks dominasi pada lokasi penelitian adalah sebesar 0,001 sebagaimana dapat dilihat pada tabel 6. Dalam tabel tersebut yang mempunyai nilai dominasi tertinggi sebelah Selatan sebesar 0,003 . Hal inimenunjukan bahwa terdapat dominasi spesies tertentu yaitu Holothuroidea. Tidak

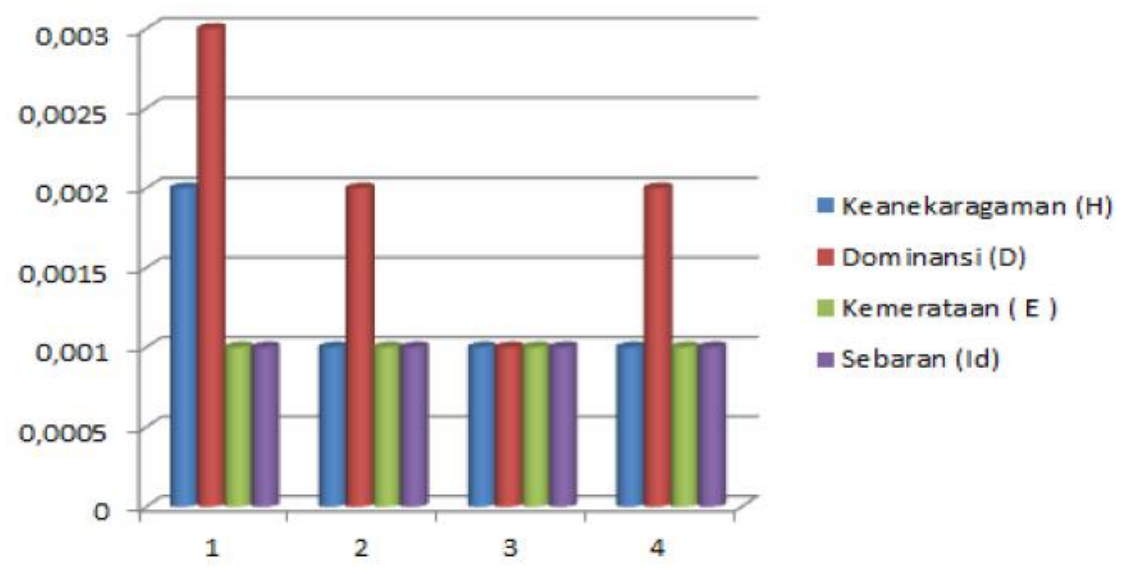

Gambar 4. Keanekaragaman, dominansi, kemerataan, dan pola sebaran jenis ekinodermata pulau Keffing.

Figure 4. Diversity, dominance, evenness, and distribution patterns of species Keffing Island echinoderms. 
adanya dominasi spesies tertentu ini kemungkinan berhubungan erat dengan keberadaan biota tersebut yang tidak beragam. Selanjutnya dikatakan bahwa dominasi terjadi karena adanya hasil dari proses kompetisi penggusuran individu satu terhadap yang lain atau disebabkan karena karakter habitat jenis spesies tertentu yang hidup menyebar hampir pada semua zona yang ada (Leksono, 2007).

\section{c. Kemerataan}

Secara umum nilai rata-rata indeks kemerataan 0,001 sebagaimana dapat dilihat pada Tabel 6. Pada tabel tersebut menunjukan bahwa, kemerataan spesies pada setiap lokasi penelitian tidak menyebar secara merata. Nilai indeks kemerataan spesies $<0,6$ maka kemerataan antar spesies rendah dan jika nilai indeks kemerataan spesies $>0,8$ maka kemerataan antar spesies tinggi (Romimohtarto \& Juwana, 2011). Selanjutnya dikatakan bahwa sebaran biota disebut seimbang atau merata apabila indeks kemerataan berkisar antara 0,6-0,8 (Odum, 1963). Pengertian sebaran merata apabila dilakukan transek berulangulang atau koleksi bebas di sembarang lokasi maka peluang untuk mendapatkan hasil yang sama adalah besar. Tidak meratanya sebaran biota di suatu ekosistem diartikan sebagai telah terganggunya ekosistem tersebut. Selanjutnya dikatakan bahwa jika spesies-spesies yang ditemukan pada suatu komunitas memiliki jumlah individu tiap spesies yang sama atau hampir sama, maka kemerataan di komunitas tersebut menjadi tinggi. Ketidakmerataan jenis ekinodermata tersebut diduga disebabkan oleh penyebaran jumlah individu tiap jenis tidak menyebar secara merata, atau disebabkan karena faktor fisika-kimia lingkungan perairan tersebut (Krebs, 1989).

\section{d. Pola Sebaran Jenis}

Nilai indeks pola sebaran jenis (Id) tiap stasiun penelitian $<1$ dan nilai rata-rata indeks sebaran 0,001 sebagaimana dapat dilihat pada Tabel 6 . Nilai indeks pola sebaran jenis, Id $=1$ menunjukan penyebaran acak, Id $<1$ menunjukan penyebaran ragam, dan Id $>1$ menunjukan penyebaran berkelompok (Brower, 1990). Tidak beragamnya nilai sebaran kemungkinan disebabkan oleh faktor perubahan habitat seperti pasir, lamun dan terumbu karang yang ada dimana habitat di daerah ini sudah sulit untuk semua jenis ekinodermata dapat beradaptasi dengan lingkungannya.

\section{KESIMPULAN}

Berdasarkan hasil penelitian, diperoleh kesimpulan bahwa jenis-jenis ekinodermata pada kegiatan kegiatan trasnsek dan koleksi bebas yang dilakukan di daerah pasang surut perairan Pulau Keffing, ditemukan ekinodermata keseluruhannya berjumlah 6 jenis, 7 famili, 4 kelas, dengan jumlah keseluruhan 352 individu. Nilai frekuensi kehadiran ekinodermata di perairan Pulau Keffing adalah sebesar 40,00\% sedangkan nilai kepadatan sebesar $0,107 \mathrm{ind} / \mathrm{m}^{2}$.

\section{UCAPAN TERIMA KASIH}

Penulis mengucapkan terima kasih kepada pengelola Jurnal Kelautan dan Perikanan Terapan (JKPT) atas masukan dan saran serta penerbitan pada artikel ini.

\section{DAFTAR PUSTAKA}

Andilala, N., Khalallia, F. B. R., Maharani, S. E., Ramadhani, P. H., Huda, A. M., Putri, A. F., Alda, B., ... Epilurahman, R. (2020). The diversity of echinoderm in Sarangan beach, Gunung Kidul, Yogyakarta. IOP Conf. Series: Earth and Environmental Science 404, 1-8.

Bakus, G.J. (1973). The Biology and Ecology of Tropical Honolthurians in Jones, O.A. and R. Endean (Eds). Biology and geology of coral reef. Academic press. London, 326-367.

Brower, J. E. H.Z. (1990). Field and laboratory methods for general ecology. USA, New York: Win. C. Brown publisher, 52-53.

Chelazzi, G. \& Vannini, M. (1980). Zonation of intertidal mollusks on rocky shore of Southern Somalia. Estuarine and coastal marine science, 10, 569-584.

Clark, A. M. \& Rowe, F.W.E. (1971). Monograph of shallow water Indo-West Pasific echinoderms. Trustess of the british museum (natural hystory), London : $238 \mathrm{pp}$.

De Beer, M. (1990). Distribution patterns of regular sea urchin (Echinodermata: Echinoidea) across the Spermonde Shelf SW Sulawesi Indonesia. Proceeding of the second European conference on echinoderms, Brussel/Belgium 18-21 September 1989 (eds. De Ridder, Dubois, Lahaye and jangoux) : 165-170.

Jailani, A. K., Sahami, F. M., \& Kadim, M. K. (2020). Abundance and diversity of echinoderms in seagrass and coral reefs ecosystems. Jurnal IImiah Perikanan dan Kelautan, 8 (2), 33-36.

Krebs, C. J. (1989). Ecology of experimental analysis of distribution and abundance. Second Edition. New York: Harper and Row Publishers, 654 pp.

Leksono, A. S. (2007). Ekologi: Pendekatan deskriptif dan kuantitatif. Bayumedia publishing. Ludwig, 210 hal.

Magalf. R. (1957). La teoria de la information en 
ecologia. Mem, R. Acad. Sci. J. Arte, Barcelona, 32, 373-449.

Mustofa, A. (2014). Frekuensi kematangan gonad teripang (Holothuroidea) di pantai Bandengan, Kabupaten Jepara. Jurnal DISPROTEK, 5 (1), 4454.

Muzaki. F. K., Setiawan, E., Insyany, G. F. A., Dewi, N. K., \& Subagio, I. B. (2019). Community structure of echinoderms in seagrass beds of Pacitan beaches, East Java, Indonesia. Biodiversitas, 20 (7), 1787-1793.

Odum, E. P. (1971). Fundamental of ecology. Philadelphia London Toronto : W.B. Souders Company, 544 pp.

Radjab, A.W. \& Rumahenga, S.A. (2012). Keanekaragaman jenis ekinodermata di perairan Jikumerasa, Kabupaten Buru, Maluku. Prosiding pertemuan ilmiah nasional tahun IX ISOI. Arafura and Timor Sea Ecosystem Action (ATSEA), 143152.

Rahayu, D.L. (1984). Keanekaragaman jenis dan biomas rumput laut di beberapa daerah Maluku Tengah. Oseanologi di Indonesia, 18, 21-34.
Romimohtarto, K. \& Juwana, S. (2011). Biologi laut. Ilmu pengetahuan tentang biota laut. Djambatan, Jakarta, 540 hal.

Rowe. F. W. E. \& Doty, J. E. (1977). The shallow-water holothurians of Guam. Micronesia, 13 (2), 217250.

Sese. M. R., Annawaty., \& Yusron, E. (2018). Keanekaragaman ekinodermata (Echinoidea dan Holothuroidea) di Pulau Bakalan, Banggai Kepulauan, Sulawesi Tengah, Indonesia. Scripta biologica, 5 (2), 73-77.

Syamsul, B., Patech, L. R., Zulhalifah, Septiani, D. A., \& Siswadi. (2021). Distribution and diversity of echinoderms in the coastal waters of south beach of Lombok Island. Jurnal Biologi Tropis, 21 (1), 22-31.

Shannon, C.E. (1948). A mathematical theory of communication. Bull. Syst. Tech. J., 27, 379-423.

Taylor, J.D. (1971). Reef associated molluscan assemblage in the western Indian Ocean. Symposium of the zoological society of London, 28, 510-534. 
Lampiran 1. Jenis-jenis ekinodermata di perairan Pulau Keffing, Seram Bagian Timur, Maluku.

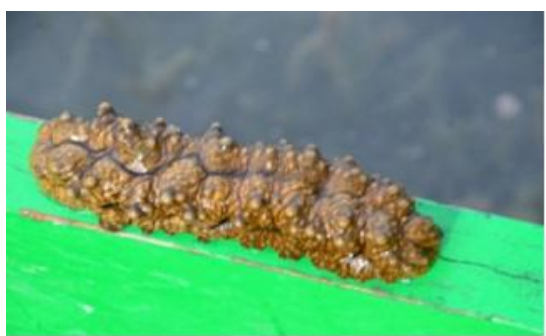

Spesies : Stichopus variegatus

Famili : STICHOPODDIDAE

Kelas : HOLOTHUROIDEA

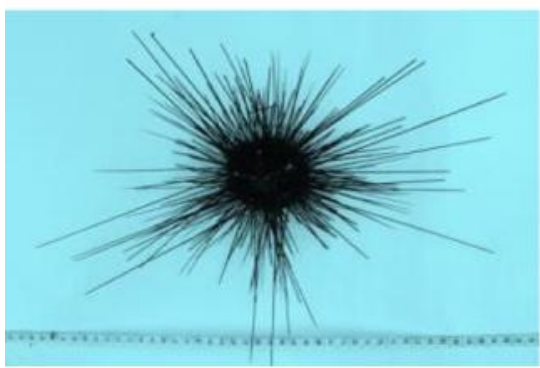

Spesies : Diadema setosum

Famili : DIADEMATIDAE

Kelas : ECHINOIDEA

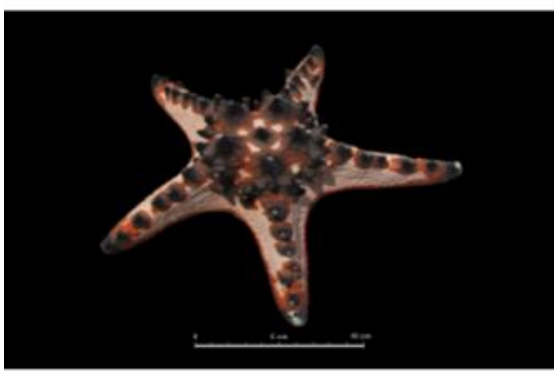

Spesies : Protoreaster nodosus

Famili : OREASTERIDAE

Kelas : ASTERIODEA

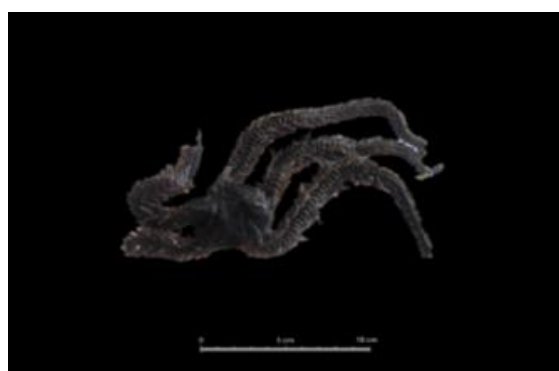

Spesies : Ophiocoma erinaceus

Famili : OPHIOCOMIDAE

Ordo : OPHIURIDEA

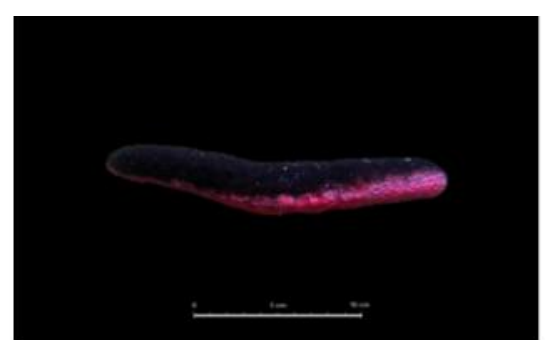

Spesies : Holothuria edulis

Famili : HOLOTHURIIDAE

Kelas : HOLOTHUROIDEA

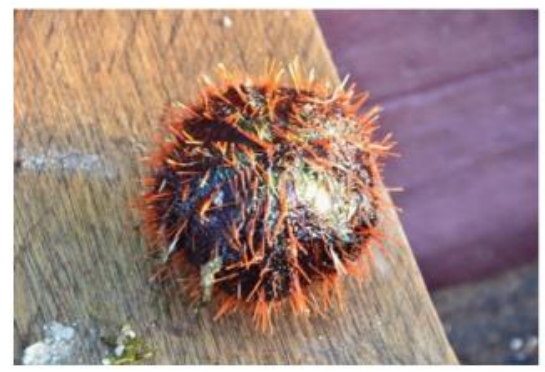

Spesies : Tripneustes gratilla

Famili : TOXOPNEUSTIDAE

Kelas : ECHINOIDEA

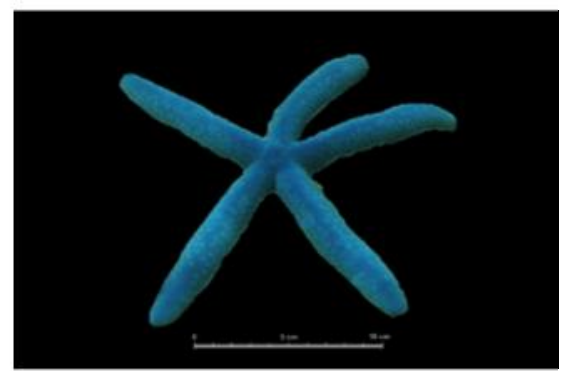

Spesies : Linckia laevigat

Famili : OPHIDIASTERIDAE

Kelas : ASTERIODEA 